\title{
Salmonella haemorrhagic bullae
}

\author{
Hsu-Tang Cheng \\ Department of Plastic and Reconstructive Surgery, China Medical University Hospital, China Medical University, Taichung, Taiwan
}

Correspondence to Dr Hsu-Tang Cheng, hsutangcheng@gmail.com

\section{DESCRIPTION}

A 72-year-old man presented to our hospital with a 3-day history of fever, right foot pain and swelling and a huge bulla (blister) on the right dorsal foot (figure 1). The patient had poorly controlled type 2 diabetes mellitus and chronic obstructive lung disease. Right foot pain and swelling had been evident for more than 2 months and care had been sought at the patient's primary care physician. The patient had been treated as arthritic. No trauma or recent diarrhoea was recalled. The patient had not drunk raw milk or consumed uncooked meat or eggs. On physical examination, the patient was alert but weak. There were several bullae with the largest one being $8 \times 9 \mathrm{~cm}$ in size on the right dorsal foot. The patient had a white cell count of $14870 / \mathrm{mm}^{3}$, with $77.6 \%$ segmented neutrophils, haemoglobin of $9.2 \mathrm{gm} / \mathrm{dl}$, platelet count of $100000 / \mathrm{mm}^{3}$, creatinine level of $3.02 \mathrm{mg} / \mathrm{dl}$, blood glucose level of $353 \mathrm{mg} / \mathrm{dl}$ and a C reactive protein of more than $38 \mathrm{mg} / \mathrm{dl}$.

On the second hospital day, the bullae ruptured spontaneously. The skin overlying the bullae revealed necrotic (figure 2). Cultures from the bullae and blood yielded solely Salmonella eteritidis group D. Surgical treatment was postponed because of severe gastrointestinal bleeding, poor lung function and persistent thrombocytopenia. On the sixth hospital day, the patient had aspiration pneumonia and developed respiratory failure. After being transferred to the intensive care unit, the condition deteriorated into septic shock and the patient died because of multiple organ failure.

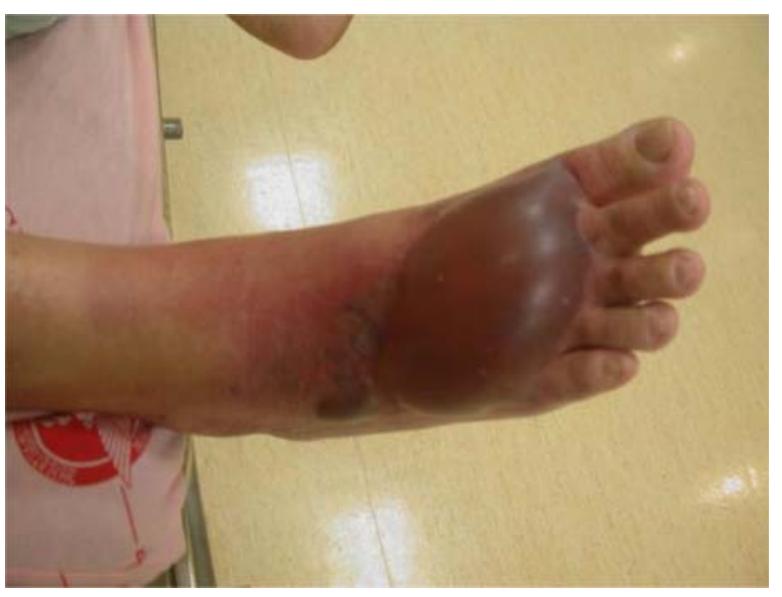

Figure 1 Initial appearance of the affected foot. Upon arriving at the emergency room, a large bulla at dorsal foot that resembled a second-degree burn was evident.

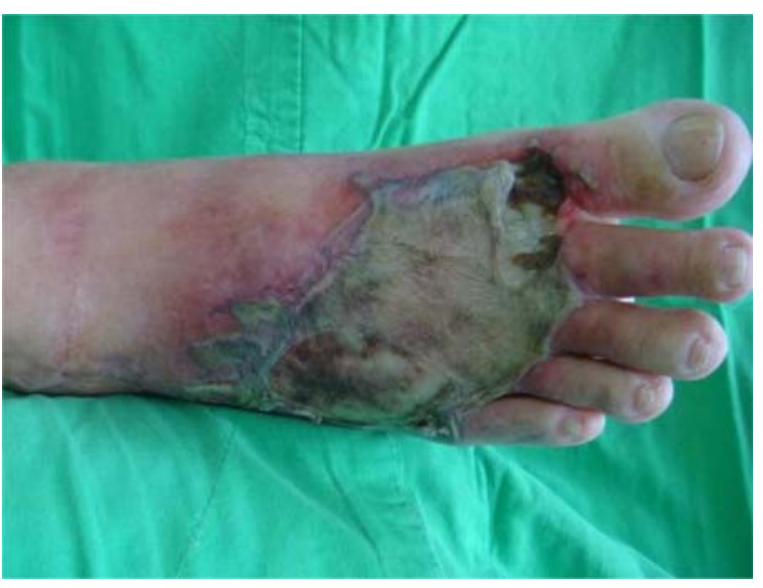

Figure 2 Appearance of the foot during hospitalisation. On the second day of hospitalisation, the bullae ruptured and presented as necrotising fasciitis.

\section{Learning points}

- Salmonella enteritidis is a member of the non-typhoid Salmonella.

- It is a Gram-negative motile bacillus that causes infections with different clinical presentations, most commonly gastroenteritis. Extraintestinal focal infections (EFIs) from Salmonella may affect different sites in the body, causing different disorders, which frequently occur during or after Salmonella bacteraemia in patients with underlying systemic diseases. ${ }^{1}$

- Diabetes mellitus and HIV infection are the most common predisposing illness for systemic Salmonella infections. ${ }^{2}$ However, necrotising fasciitis is a rare form of EFI. In the present case, the dorsal foot bullae, although resembling a second degree burn injury, was regarded as 'haemorrhagic bullae', which are usually related to necrotising fasciitis. ${ }^{3}$

- Necrotising fasciits is a life-threatening and limb-threatening soft tissue infection, but is an uncommon manifestation of Salmonella infection.

- Prompt diagnosis combined with timely surgical intervention and appropriate antibiotics are the key factors to positive patient outcome. 


\section{BMJ Case Reports}

\section{REFERENCES}

1. Hsiao CT, Lin LJ, Shiao CJ, et al. Hemorrhagic bullae are not only skin deep. Am J Emerg Med 2008;26:316-19.

2. Chen PL, Chang CM, Wu CJ, et al. Extraintestinal focal infections in adults with nontyphoid Salmonella bacteraemia: predisposing factors and clinical outcome. J Intern Med 2007;261:91-100.
3. Bahar G, Dansuk Z, Kocatürk $S$, et al. Abscess of the neck caused by Salmonella enteritidis. Otolaryngol Head Neck Surg 2003;129:445-7.

This pdf has been created automatically from the final edited text and images.

Copyright 2012 BMJ Publishing Group. All rights reserved. For permission to reuse any of this content visit http://group.bmj.com/group/rights-licensing/permissions.

BMJ Case Report Fellows may re-use this article for personal use and teaching without any further permission.

Please cite this article as follows (you will need to access the article online to obtain the date of publication).

Cheng H-T. Salmonella haemorrhagic bullae. BMJ Case Reports 2012;10.1136/bcr-10-2011-4923, Published XXX

Become a Fellow of BMJ Case Reports today and you can:

- Submit as many cases as you like

- Enjoy fast sympathetic peer review and rapid publication of accepted articles

- Access all the published articles

- Re-use any of the published material for personal use and teaching without further permission

For information on Institutional Fellowships contact consortiasales@bmjgroup.com

Visit casereports.bmj.com for more articles like this and to become a Fellow 